\title{
Research and Development: Model of Clinical Collaborative Supervision for Scientific Based English Instruction
}

\author{
Supriyono ${ }^{1}, *$ Hesty Puspita Sari ${ }^{2}$ \\ ${ }^{1,2}$ Universitas Islam Blitar, J1. Majapahit No.2-4, Blitar, Indonesia \\ *hestypuspita1403@gmail.com
}

\begin{abstract}
This research aimed to establish an instructional supervision model for scientific-based English instruction at Islamic Junior Boarding Schools. Research questions were stated as to how was the formulation of the model. This research employed Research and Development with three phases of (1) foundational study seeking the potencies and problems using policy analysis, field study, and theoretical review; (2) design and development study by designing the hypothetical model and developing the model formulation to be validated; and (3) Try out the study by doing one group pre-post experimental and perceptional studies. Finally, the model was established informs of model book and tutorial usage. The model combined principles of clinical Supervision and collaborative orientation to control, which were compatible with the behavioural characteristic of Islamic Boarding Junior High Schools in a pesantren environment. This model obtained score validation of $89 \%$, categorized as valid, can be used without revision. While the pre-assessment score was 2.60 and the postassessment score was 3.39with, the t-test was -7.0886on significant 0.05 and t table 2.447. This model was concluded to be practical and applicable to use as a Scientific Based English Instruction Supervision for Islamic Boarding Junior High Schools.
\end{abstract}

Penelitian ini bertujuan untuk membentuk model supervisi pembelajaran bahasa Inggris berbasis saintifik di Pesantren. Pertanyaan penelitian dinyatakan sebagai bagaimana perumusan model. Penelitian ini menggunakan Research and Development dengan tiga tahapan proses yang terdiri dari (1) studi dasar mencari potensi dan permasalahan dengan menggunakan analisis kebijakan, studi lapangan, dan telaah teoritis. (2) studi desain dan pengembangan dengan merancang model hipotetis dan mengembangkan formulasi model untuk divalidasi; dan (3) Try out study dengan melakukan one group pre-post eksperimental study dan preceptionalstudy. Terakhir, model yang dibentuk menginformasikan buku model dan penggunaan tutorial. Model tersebut memadukan prinsip supervisi klinis dan orientasi kolaboratif terhadap supervisi yang sesuai dengan karakteristik perilaku ponpes di lingkungan pesantren. Model ini memperoleh validasi skor $89 \%$ yang dikategorikan valid, dapat digunakan tanpa ada revisi. Sedangkan nilai pre-assessment 2,60 dan post-assessment score 3,39 dengan t-test -7,0886 pada signifikan 0,05 dan t tabel 2,447. Disimpulkan bahwa model ini efektif dan aplikatif untuk digunakan sebagai metode Pengawasan Pembelajaran Bahasa Inggris Berbasis Ilmiah pada SMP Pesantren. 
Keywords: Supervision, Clinical, Collaborative, English Instruction, Scientific.

Received: July 26, 2021; Revised: Agust 18, 2021; Accepted: December 1, 2021

\section{INTRODUCTION}

Islamic boarding schools have become integral parts of Indonesian education (Ikhwan, 2017). These schools are managed by Islamic institution, the so-called Pondok Pesantrens, as indigenous education, which has been phenomenal. Today most of them organize both religious and formal instructions such as Schools. They become the central attention of families and communities who demanded moral and spiritual education (Ikhwan, Biantoro and Rohmad, 2019). At Junior High Schools, they provided foreign language instructions, both Arabic and English. English turned out to become essential to learn both in class and outside classrooms for speaking developing skills. It has been interesting to study as English is known at the same time as Arabic.

Participants' participative observation in East Java, Indonesia, from June to July 2019 showed that English was considered the flagship lesson and unique program as Arabic was. The English program was observed because there are no activity subscriptions besides the researcher's background in education management and English education. Results of an interview with these two schools leaders, the so-called Kyai, Principals, Teachers, and Students confirmed that English and Arabic were prioritized foreign language subjects to learn formally and informally (Ikhwan et al., 2020). Even though students were enthusiastic, teachers still found it challenging to implement the 2013 English curriculum using the scientific approach. They needed on going professional development. It is essential that teachers are professional (Mutohar, 2006), but not all teachers can efficiently work professionally (Imron, 2011). Thus, professional assistance shall be given (Zepeda, 2007). Supervision can be the way to support on going professional development (Suhardan, 2010). A suitable model of English Instructional Supervision was needed. In his research on the participative supervision model in Pondok Pesantren, he found out that Kyai, Principals, Vice Principals, and Teachers focused on teachers' disciplines and behaviour (Supriyono, 2018). There were still problems in teachers professional supports. The practice of collaborative c munication showed positive results of teachers' professional improvement. Supervision was expected to be a problem-solving alternation.

This research proposed establishing clinical and collaborative Supervision for scientific-based English instruction of Islamic Boarding Junior Middle Schools. The research question was formulated about how the established clinical joint Supervision for Scientific based English Instruction of Islamic Boarding Middle Schools was formed. This research was expected to provide continuous professional development for English teachers at Islamic Boarding Middle Schools.

Instructional Supervision has been necessary for the life of education (Zukhrufin, Anwar and Sidiq, 2021). Educational supervision consisted of two kinds of supervision, which are managerial and academic supervisions (Direktorat Pembinaan Tenaga Kependidikan, Pendidikan Dasar dan Menengah, 2016);(Kementrian Pendidikan dan Kebudayaan, 2013). Academic Supervision is instructional Supervision (Supriyono, 2017). This is considered as continuous professional assistance for teachers to implement their professional educational tasks. Glickman et 
al. stated that this is given so that teachers enhance their professional works (Glickman, Gordon and Ross-Gordon, 1987). In this case, supervisors attempt to improve the quality of education under their responsibilities and accountabilities of teachers' professional development (Direktorat Tenaga Kependidikan, 2007). Instructional Supervision has been practised in various approaches, supervisory behavioural orientation, and techniques.

Approaches of Supervision consisted of scientific approach, artistic approach, Supervision as democratic, and clinical Supervision. Scientific Supervision has emerged in the school system since 1961 (Gwyn, 1961); Eisner in (Sergiovanni, 1982). Scientific Supervision is based on the scientific method to measure teachers performance using standardized tests and measurements and objective measurements in teaching and to learn to count the instructional administration to improve teaching and learning achievements. Even though such Supervision can capture the teacher's area of development, this has been critiqued for 5 (five) things; which were, (1) inability to capture behaviour due to just using checks of administrative lists, (2) the holistic assumptions which are unable to capture smaller parts of the measured components individually, (3) observation as an exclusive action avoiding descriptive capture of phenomena, (4) the isolation of educational variables, and (5) having the method to ignore processes. Artistic Supervision appeared to respond to such situations (E.W., 1982).

Artistic Supervision gives more attention to creativity and expressive characters or the unique contribution of teachers (Minnear-Peplinski, 2009). This is the opposite of scientific Supervision. Both of these supervisory models stayed in their principles. The former is full of rigid rules, while the latter is full of artistic actions. Meanwhile, teachers highly have needed professional development to solve their problems. Requiring to support teachers for problem-solving, clinical Supervision has been introduced.

Clinical Supervision provides supervisory, professional services by having face to face conferences among supervisors and teachers (Sergiovanni and Staratt, 1983). Sullivan and Glaze see this as teachers' performance guidance to manage their teaching and learning process. Such assistance is done in the systematic cycle (Garman, 1982). The recurring cycle consists of pre-observation meetings among teachers and supervisors, supervisory observation in classes by supervisors, and post-observation meetings (Goldhammer, Anderson and Krajewski, 1993). Such cycle can be summarized as preobservation, statement and post-observation. In the pre-observation phase, supervisors committed to meeting teachers to identify problems, discuss solutions, and commit observation schedules. In the observation phase, the supervisors observe teachers organize and manage teaching and learning processes and identify the issues for development. In the post-observation step, supervisors provide feedback to teachers. And agree to the follow-up. This kind of Supervision has been acknowledged to be effective and can improve teachers competencies in classroom practices (Salma, Yusrizal and N., 2018). Even though this clinical Supervision is beneficial, there still has been handicaps to implement it. Principles still have problems using this. Barriers in clinical Supervision turns out to be the minimum teachers' understanding, having limited time to work on this-supervisors' lack of competence and teachers enthusiasm. One way to solve such problems is providing information technology using SMS (Ruqaiyah, 2016). This Supervision helps teachers do a self-assessment and do personal development. The principal offers face to face feedback. 
They introduced Supervision as developmental with 4 (four) kinds of supervisory behaviour clusters, which Supriyono, Imron, Arifin, and Kusmintardjo identified as an orientation to supervisory behaviour (Supriyono et al., 2017). These four behaviour clusters are Directive informational, Directive controlled, Collaborative, and NonDirective. These have differences in the way how supervisors and teachers behave in the interaction of Supervision. The Directive edifying is characterized by the dominance of the supervisor but giving more room to teachers to offer their ideas and solution. The Directive controlled tends to place supervisors as leaders who tell and order. Teachers have small opportunities to state their opinions. Cooperative behaviour is characterized by mutual respect and understanding among supervisors and teachers, and they have similar rights to express their ideas and contribute their solutions. The Non Directive behaviour place more freedom on teachers, and supervisors often listen to teachers.

English instruction at Islamic Boarding Middle Schools employs national regulation with the 2013 curriculum. This curriculum requires a scientific approach. This approach involves investigating phenomena to gain new knowledge and correct or combine it with previous knowledge. In practice, this approach was implemented by (1) observing, (2) questioning, thinking, trying, and making networks. Sriwahyuni found out that such procedures were visible to teachers supported by principals with media (Sriwahyuni, 2015). This approach was also found out to enhance students learning achievements.

Theoretically and empirically, clinical Supervision can help enhance teachers professional capabilities, collaborative behaviour provides harmonic interaction among supervisors and teachers, and the scientific approach tends to force teachers to be experienced in managing the classrooms.

\section{METHOD}

This research was the research and development in nature which refers to qualitative and quantitative approaches. Based on the adaptation of Sugiyono (2013) R and D design, this research was done in three phases, which were (1) foundational study to identify potencies, problems and possible solutions, (2) design and development study using the reference of ADDIE model, and (3) try out a study using one group pre-post assessment and perceptional study. In the first phase, the policy study concerned the content analysis of the English curriculum and supervisory policies using a contentanalytic matrix (Miles, Hubberman and Saldana, 2014). The Field study is concerned with multisite studies. The sites of this study were two Islamic Boarding Middle Schools, which were Bustanul Muta'alimin Salafi Entrepreneurial Islamic Boarding Schools and Anharul Ulum Santripreneurial Islamic Boarding Schools, East Java, Indonesia. Key informants were taken by purposive sampling with snowballing technique. Data were collected using observation, interviews, and documentation. Participative and passive words were used with field notes. In-depth interviews were done by probing method, and using interview notes as for recording was not allowed.

Meanwhile, check list matrix was used to record data from the documentation. The validity and reliability of the data were analyzed by using triangulation of method and sources. Data were analyzed using interactive analysis with observation contact summary, interview contact summary, and content-analytic matrix. 
At the second phase, both in the process of design and development, Experts validators were assigned to validate the model and its formulation. Validation criteria were used to make sure that the model was valid to be tried out. In the third phase, the model was tried out using one group pre-post test. The main subjects of this phase of research were English teachers, Principals, and Kyai. Data were collected by using supervisory assessment measurements and analyzed by using a t-test. The perceptional study was used to find out the suitability of the model. After being tried out, the model was evaluated and revised for finalization. The final product of this model was the model itself presented in the book and tutorial video. The following was the research framework.

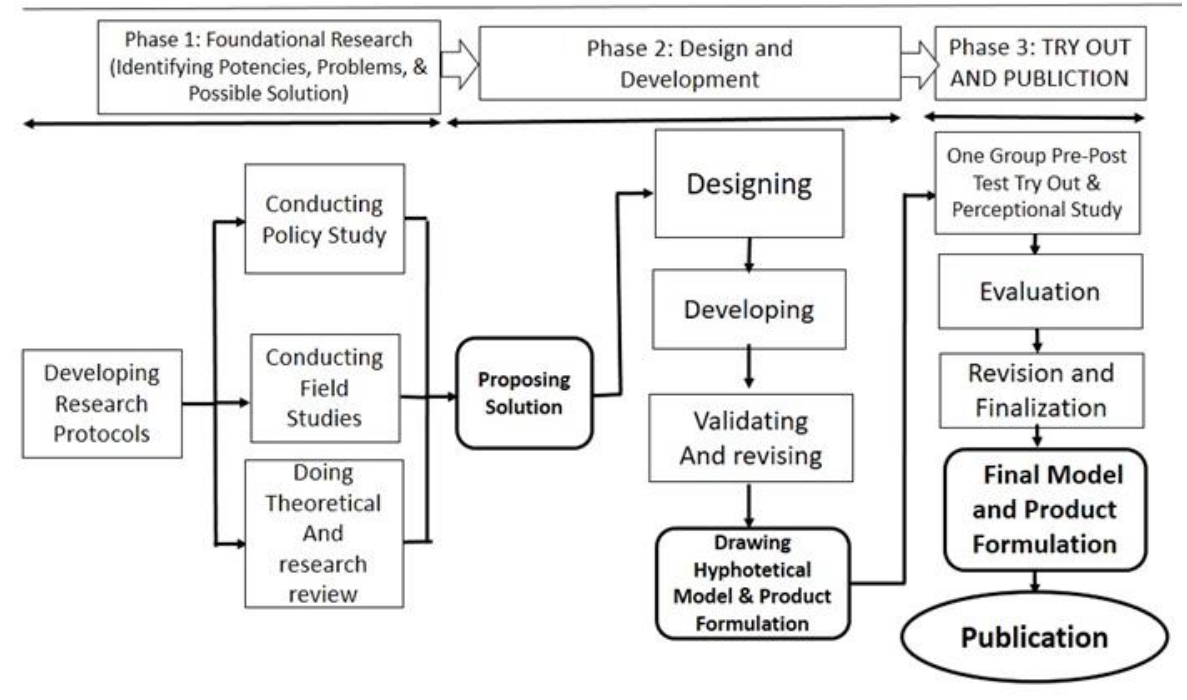

Figure 1. Research Framework adapted from Sugiyono (2013) @2020 Supriyono \& Puspita.

\section{RESULT AND DISCUSSION The Result of Analysis}

The policy analysis on the 2013 curriculum revealed that English Instruction was required to use a scientific approach. Teachers were required to be competent and were to develop their continuous professional development (KBJ01-KUR13-2020) ${ }^{1}$. Academic Supervision was meant to be professional assistance of teachers' continuous professional development. The policy analysis on the principal's development revealed the usage of clinical Supervision and collaborative approach to Supervision (KBJ02SUPAK-2020) ${ }^{2}$.

Cross case analyses of two sides resulted in the following findings: (1) English was taught based on the 13 Curriculum, (2) English was taught by using a scientific approach, but teachers still were not accustomed to using a scientific approach and needed ongoing professional development (3) There was instructional supervision practice containing clinical and collaborative supervision elements, but was not systematic and consistent, (4) There was a need of supervision model that could solve instructional problems, enhance teachers' performance, contain collegial relationship, interactive, cooperation, and the so-called tabayun (check and recheck/ confirm). These findings showed that ongoing teacher professional development in teaching English using a scientific approach was the main problem. There were potencies of 
using clinical Supervision that allowed problem-solving and collaborative supervisory behaviour that allowed teachers' contribution ideas for professional development. Therefore, it was proposed to design, develop, and research clinical collaborative supervision for the scientific-based English Instruction of Islamic Boarding Middle Schools.

This proposal was highly recommended as a result of theoretical review and researchsupported such proposal. Sulivan dan Glanz confirmed that clinical Supervision could be on going professional development that was cyclically systematic, collegial, collaborative, and ethical (Sullivan and Glanz, 2005). Garman said that this Supervision could be used to solving problems (Garman, 1982). Meanwhile, Glickman, Gordon, and Ross Gordon confirmed that collaborative supervisory behaviour enabled teachers to identify their problems, articulated their concerns, and propose solutions to their supervisors (Glickman, Gordon and Ross-Gordon, 2009). Research by Supriyono showed that the notions for clinical and collaborative elements in Supervision were compatible with the behavioural habit of Islamic Boarding Middle Schools.

\section{The Result of Design and Development}

The design and development resulted in the following findings: (1) The model prototype contained components of preparation, implementation, and evaluation, (2) content of the model consisted of formative and summative instructional supervision plan, clinical and collaborative supervisory implementation, and (3) evaluation of teachers performance and students achievement as well as feedbacks from the Supervisors to Teachers (Form and formulation of the model are presented in final model section). The results of model prototype validation were as the followings.

Table 1. The score of the model prototype design validation

\begin{tabular}{lll}
\hline No & Description & Score \\
\hline 1 & Expert 1 & 92 \\
2 & Expert 2 & 90 \\
3 & Expert 3 & 86 \\
Total & 268 \\
Average & 89 \\
\hline Percentage & $89 \%$ \\
\hline
\end{tabular}

Percentage $=268 / 300 \times 100=89 \%$. Criteria of the measurement (Reduwan, 2010).

Table 2. Validation criteria and validity level

\begin{tabular}{ll}
\hline Validation criteria & Validity level \\
\hline $81.0 \%-100,0 \%$ & Valid can be used without any revision \\
$61.0 \%-80.9 \%$ & Valid enough, can be used with few revision \\
$41.0 \%-60.9 \%$ & $\begin{array}{l}\text { Less valid, it is better not to be used. Need } \\
\text { revision. }\end{array}$ \\
$21.0 \%-40.9 \%$ & Invalid, cannot be used
\end{tabular}

This showed that the model was valid with no revision. The recommendation was given to provide more guidance in making preliminary meetings among Kyai and teachers. Results of the teacher's supervision pre-assessment were in three phases. 
They are 1). Before teaching and learning, 2). During the process of teaching and learning, 3). And after teaching and learning as the followings:

Table 3. The result of pre-assessment

\begin{tabular}{llrrrrrrr}
\hline \multirow{2}{*}{ No Deskripsi } & \multicolumn{7}{c}{ Respondent's score } \\
\cline { 3 - 8 } & & AU-1 & AU-2 & AU-3 & BM-1 & BM-2 & BM-3 & BM-4 \\
\hline 1 & 1.1 Instrument of Supervision on teaching and learning adminis & 2,45 & 2,55 & 2,50 & 2,55 & 2,41 & 2,50 & 2,59 \\
& 1.2 Instrument on developing syllabus & 3,00 & 2,57 & 2,52 & 2,78 & 2,91 & 2,52 & 2,57 \\
& 1.3 Instrument on developing teaching plan & 2,65 & 2,56 & 2,50 & 2,71 & 2,68 & 2,50 & 2,65 \\
2 & Instrument on learning activity supervision & 2,27 & 2,70 & 2,70 & 2,53 & 2,43 & 2,70 & 2,57 \\
3 & Instrument on scoring supervision & 2,62 & 2,54 & 2,69 & 2,62 & 2,77 & 2,69 & 2,46 \\
\hline & TOTAL & $\mathbf{1 2 , 9 8}$ & $\mathbf{1 2 , 9 1}$ & $\mathbf{1 2 , 9 1}$ & $\mathbf{1 3 , 1 8}$ & $\mathbf{1 3 , 2 0}$ & $\mathbf{1 2 , 9 1}$ & $\mathbf{1 2 , 8 3}$ \\
\hline AVERAGE & $\mathbf{2 , 6 0}$ & $\mathbf{2 , 5 8}$ & $\mathbf{2 , 5 8}$ & $\mathbf{2 , 6 4}$ & $\mathbf{2 , 6 4}$ & $\mathbf{2 , 5 8}$ & $\mathbf{2 , 5 7}$ \\
\hline & PERCENTAGE & $\mathbf{6 5 \%}$ & $\mathbf{6 5 \%}$ & $\mathbf{6 5 \%}$ & $\mathbf{6 6 \%}$ & $\mathbf{6 6 \%}$ & $\mathbf{6 5 \%}$ & $\mathbf{6 4 \%}$ \\
\hline
\end{tabular}

The average score of pre-assessment showed 2,60, similar to $65 \%$ achievement. This score is used as an essential step for the process of Supervision. Results of the supervision process assessment were as the followings:

Table 4. The development of the process assessment

\begin{tabular}{llrrrrrrr}
\hline \multirow{2}{*}{ No Deskripsi } & \multicolumn{7}{c}{ Respondent's score } \\
\cline { 3 - 8 } & 1.1 & AU-1 & AU-2 & AU-3 & BM-1 & BM-2 & BM-3 & BM-4 \\
\hline 1 & Instrument of Supervision on teaching and learning adminis & 2,68 & 2,95 & 2,77 & 2,77 & 2,68 & 2,77 & 2,68 \\
& 1.2 Instrument on developing syllabus & 3,09 & 3,00 & 3,00 & 2,96 & 3,09 & 3,00 & 2,87 \\
& 1.3 Instrument on developing teaching plan & 2,88 & 3,06 & 2,88 & 3,09 & 3,00 & 2,88 & 2,91 \\
2 & Instrument on learning activity supervision & 2,70 & 2,97 & 3,00 & 2,83 & 2,77 & 3,00 & 2,87 \\
3 & Instrument on scoring supervision & 2,85 & 2,69 & 2,77 & 2,92 & 2,85 & 2,77 & 2,69 \\
\hline TOTAL & $\mathbf{1 4 , 2 0}$ & $\mathbf{1 4 , 6 7}$ & $\mathbf{1 4 , 4 2}$ & $\mathbf{1 4 , 5 7}$ & $\mathbf{1 4 , 3 8}$ & $\mathbf{1 4 , 4 2}$ & $\mathbf{1 4 , 0 2}$ \\
\hline AVERAGE & $\mathbf{2 , 8 4}$ & $\mathbf{2 , 9 3}$ & $\mathbf{2 , 8 8}$ & $\mathbf{2 , 9 1}$ & $\mathbf{2 , 8 8}$ & $\mathbf{2 , 8 8}$ & $\mathbf{2 , 8 0}$ \\
\hline PERCENTAGE & $\mathbf{7 1 \%}$ & $\mathbf{7 3 \%}$ & $\mathbf{7 2 \%}$ & $\mathbf{7 3 \%}$ & $\mathbf{7 2 \%}$ & $\mathbf{7 2 \%}$ & $\mathbf{7 0 \%}$ \\
\hline
\end{tabular}

The average score of the proses assessment showed 2,88, similar to $72 \%$ achievement. The proses assessment score was increased shows that the process of Supervision run well. Results of the post-assessment were as the following:

Table 5. The result of post-assessment

\begin{tabular}{llrrrrrrr}
\hline \multirow{2}{*}{ No Deskripsi } & \multicolumn{7}{c}{ Respondent's score } \\
\cline { 3 - 8 } & AU-1 & AU-2 & AU-3 & BM-1 & BM-2 & BM-3 & BM-4 \\
\hline 1 & 1.1 Instrument of Supervision on teaching and learning adminis & 3,41 & 3,32 & 3,50 & 3,32 & 3,32 & 3,50 & 3,14 \\
& 1.2 Instrument on developing syllabus & 3,78 & 3,43 & 3,26 & 3,48 & 3,57 & 3,26 & 3,26 \\
& 1.3 Instrument on developing teaching plan & 3,53 & 3,26 & 3,29 & 3,38 & 3,32 & 3,29 & 3,26 \\
2 & Instrument on learning activity supervision & 3,33 & 3,50 & 3,57 & 3,40 & 3,33 & 3,57 & 3,40 \\
3 & Instrument on scoring supervision & 3,31 & 3,23 & 3,46 & 3,46 & 3,46 & 3,46 & 3,38 \\
\hline & TOTAL & $\mathbf{1 7 , 3 6}$ & $\mathbf{1 6 , 7 5}$ & $\mathbf{1 7 , 0 8}$ & $\mathbf{1 7 , 0 4}$ & $\mathbf{1 7 , 0 0}$ & $\mathbf{1 7 , 0 8}$ & $\mathbf{1 6 , 4 5}$ \\
\hline AVERAGE & $\mathbf{3 , 4 7}$ & $\mathbf{3 , 3 5}$ & $\mathbf{3 , 4 2}$ & $\mathbf{3 , 4 1}$ & $\mathbf{3 , 4 0}$ & $\mathbf{3 , 4 2}$ & $\mathbf{3 , 2 9}$ \\
\hline PERCENTAGE & $\mathbf{8 7 \%}$ & $\mathbf{8 4 \%}$ & $\mathbf{8 5 \%}$ & $\mathbf{8 5 \%}$ & $\mathbf{8 5 \%}$ & $\mathbf{8 5 \%}$ & $\mathbf{8 2 \%}$ \\
\hline
\end{tabular}

The average score of post-assessment showed 3,39, similar to $85 \%$ achievement. Based on pretest and post-test scores, the researcher found the t-test as follows:

T-test

$$
X 1-X 2
$$

$$
=\frac{\sqrt{\frac{\left(S 1^{2}\right.}{n 1}+\frac{s 2^{2}}{n 2}-2 r\left[\frac{s 1}{n 1}\right] x\left[\frac{s 2}{n 2}\right]}}{\sqrt{n}}
$$




$$
\begin{aligned}
& =\frac{2.60-3.39}{\sqrt{\frac{(0.17)^{2}}{7}+\frac{(0.24)^{2}}{7}-2(0.000002649)\left[\frac{0.17}{7}\right] \times\left[\frac{4.54}{7}\right]}} \\
& =\frac{-0.79}{\sqrt{\frac{0.029}{7}+\frac{0.058}{7}-[2(0.000002649)](0.0642)(0.0907)}} \\
& =\frac{-0.79}{\sqrt{0.01242-0.0000000154}} \\
& =-7.0886
\end{aligned}
$$

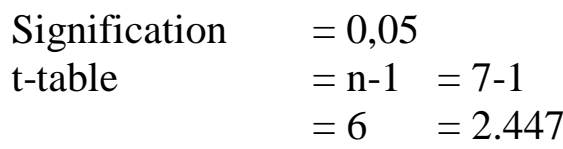

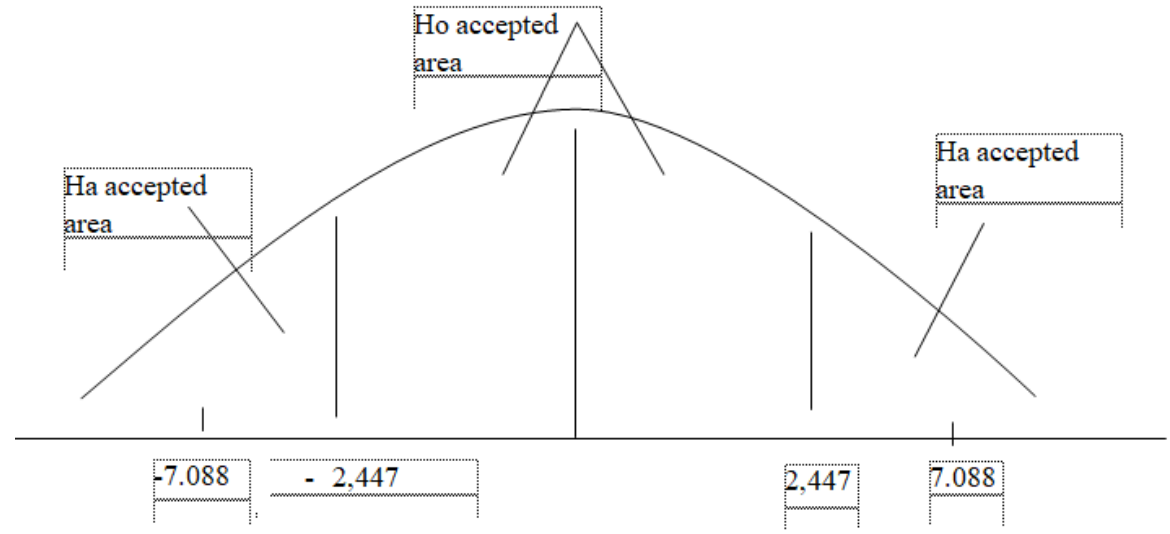

Figure 2. Trial two sides

The pre-assessment score of 2,60 and a post-assessment score of 3.39 in the 1 to 4 range. The $t$ score was -7.0886 , and the $t$ table was -2.447 . The $t$-test showed us that Ha-accepted. This means that the model of collaborative Supervision is effective to be applied to supervise the teacher on English learning based on a scientific approach. The final model was as the following: 


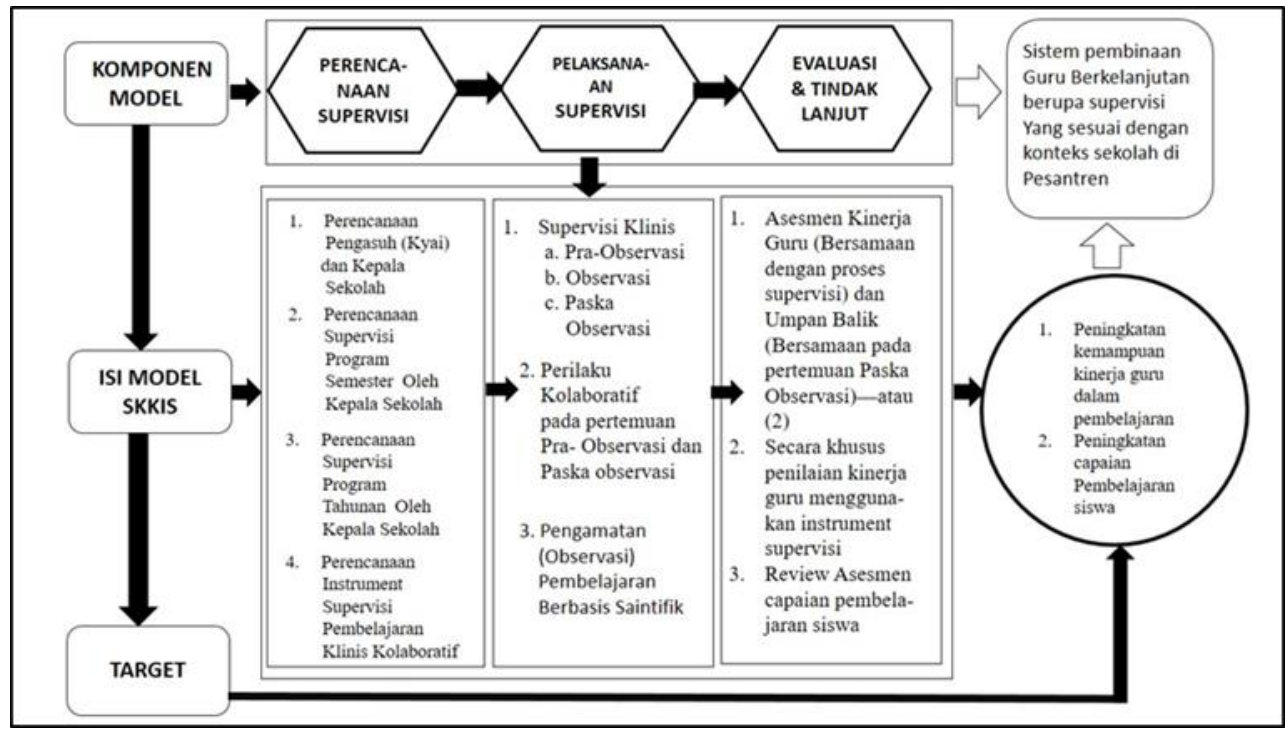

Figure 3. Model of Clinical Collaborative Supervision for Scientific Based English Instruction of the Islamic Boarding Middle Schools (Supriyono\&Puspita, 2020)

The procedures of implementing this model have been formulated as follows: (1) In supervision planning, first Kyai and Principals conduct face to face conferences to identify problems and solutions and the Principals as Supervisors formulate the semester and yearly programs, (2) In the supervision implementation, the principals conduct clinical Supervision with pre-observation, observation, and Post observation. In pre-observation and Post Observation, the Principals are advised to use collaborative behaviour orientation, and (3) In evaluation and feedback sessions, the Principals are to provide assessment results, discussions, and advice and review students' achievement. Then, feedback shall be given to Teachers with respect. The Principals and Teachers then decided to follow up.

\section{Discussion}

The Model of Clinical Collaborative Supervision for the Scientific Based English Instruction was highly valid in design and development. This also showed the practical results of the try out showing the improvement score of teacher professional practices in planning, conducting, and evaluating English instructions with the preassessment score of 2,60 and a post-assessment score of 3.39 in the 1 to 4 range. The $t$ score was -7.0886 , and the $t$ table was -2.447 showed the effectiveness of this model.

The evaluation made by experts and teachers showed that there was no revision on the model, and the model was accepted to be used for Supervision. The notion of problem-solving and professional development in this model supported current research on integrated participative instructional Supervision as problem-solving and professional development. These models also supported clinical supervision theories that could solve teachers' problems and provide professional assistance. The consistent use of the cycle and principles of the pre-observation conference, observation, and post-observation conference followed the theories as advised by (Sergiovanni \& Staratt, 2002:222); (Garman, 1982:38); and (Goldhammer, Anderson, \& Krajewski, 1993). The usage of collaborative behaviour in this supervision model was compatible with the Islamic boarding schools behaviour orientation habit allowing interactive communication and problem-solving. This showed the power of the coordinated behaviour continuum as described by Glickman, Gordon, and Ross Gordon. This 
practically turned out to provide ways in problem-solving and continuous professional development. This model was highly recommended to be used and further researched on large scales.

\section{CONCLUSION}

This research concluded that the Model of Clinical Collaborative Supervision for Scientific Based English Instruction for Islamic Boarding Schools consisted of model components, model contents, and target. The model components were consisted of preparation, implementation, evaluation and follow up. The contents included activities, behaviours, and instruments involved in the process of preparation, performance, evaluation, and follow-up. The target is concerned with the improvement of teachers' professional capacity in teaching and learning and the improvement of students learning achievement and in the process of the supervision problem-solving as in the clinical supervision approach, and collegial communication, as well as relationship ad in the collaborative behaviour orientation, were implemented. The evidence showed that this model was valid, acceptable and could be used for Scientific Based English Instructional Supervision in Islamic Boarding Middle Schools. It is suggested that the next researcher develop this model into a different school level with another subject.

\section{REFERENCES}

[1] Direktorat Pembinaan Tenaga Kependidikan, Pendidikan Dasar dan Menengah, K. P. dan K. (2016) Manajemen Supervisi Manajerial. Jakarta: Direktorat Pembinaan Tenaga Kependidikan.

[2] Direktorat Tenaga Kependidikan (2007) Pendidikan dan Latihan, Supervisi Akademik Dalam Peningkatan Profesionalisme Guru. Jakarta: Direktorat Jen-deral Peningkatan Mutu Pendidik dan Tenaga Kependidikan, Kementrian Pendidikan Nasional.

[3] E.W., E. (1982) 'An Artistic Approach to Supervision', p. 53.

[4] Garman, N. B. (1982) 'The clinical approach to supervision', Supervision of Teaching, pp. 35-52.

[5] Glickman, C. D., Gordon, S. P. and Ross-Gordon, J. M. (1987) Clarifying Developmental Supervision. Alexandria: VA: ASCD.

[6] Glickman, C. D., Gordon, S. P. and Ross-Gordon, J. M. (2009) Supervision and Instructional Leadership: A Developmental Approach. 7th ed. Boston: Pearson.

[7] Goldhammer, R., Anderson, R. H. and Krajewski, R. J. (1993) Clinical Supervision:Special methods for the supervision for the Supervision of teachers $(31$ st $E d)$. Fortt Worth: TX: Holt, Rinehart and Winston.

[8] Gwyn, J. M. (1961) Theory and Practice of Supervision. Toronto: Dodd, Mead, \& Company.

[9] Ikhwan, A. (2017) 'Metode Simulasi Pembelajaran dalam Perspektif Islam', ISTAWA: Jurnal Pendidikan Islam, 2(2), pp. 1-34.

[10] Ikhwan, A. et al. (2020) 'Revitalization of Islamic Education Teachers in the Development of Student Personality', in 1st Borobudur International Symposium on Humanities, Economics and Social Sciences (BIS-HESS 2019), pp. 162-165. 
[11] Ikhwan, A., Biantoro, O. F. and Rohmad, A. (2019) 'The Role of the Family in Internalizing Islamic Values', Dinamika Ilmu. doi: 10.21093/di.v19i2.1746.

[12] Imron, A. (2011) Supervisi Pembelajaeran Tingkat Satuan Pendidikan. Jakarta: Bumi Aksara.

[13] Kementrian Pendidikan dan Kebudayaan (2013) Supervisi Akademik. Depok: LPPKS Indonesia.

[14] Miles, M. B., Hubberman, A. M. and Saldana, J. (2014) Qualitative Data Analysis: A Methods Source Book. California: SAGE Publication.

[15] Minnear-Peplinski, R. M. (2009) Principals' and Teachers' Perceptions of eacher Super-vision. University of Nevada.

[16] Mutohar, P. M. (2006) Hubungan Gaya Kepemimpinan Kepala Sekolah, Budaya Organisasi, Iklim Organisasi, Semangat Kerja, dan Motivasi Berprestasi Guru Dengan Kinerja Guru SMPN Di Kabupaten Tulungagung. Universitas Negeri Malang.

[17] Ruqaiyah (2016) 'Pengembangan Model Supervisi Klinis Berbasis Informasi dan Teknologi', Cakrawala Pendidikan, 35(3).

[18] Salma, P., Yusrizal and N., U. (2018) 'Pelaksanaan Supervisi Klinis Dalam Meningkatkan Kompetensi Guru di MAN Beaureunuen', Jurnal Magister Pendidikan, pp. 18-23.

[19] Sergiovanni (1982) Supervision of Teaching. Alexandria: Virginia: Association for Supervision and Curriculum Development.

[20] Sergiovanni, T. J. and Staratt, R. J. (1983) Supervision for Human Perspective. New York: McGraw Hill.

[21] Sriwahyuni (2015) 'Pembelajaran Bahasa Inggris Berdasarkan Pendekatan Saintifik Kurikulum 2013 Di Kelas VII MTS Negeri Padang Luar’, Jurnal Manajemen Pendidikan Al Fiqrah, 3(2).

[22] Suhardan, D. H. (2010) Supervisi Profesional: Layanan dalam Meningkatkan Mutu Pembelajaran di Era Otonomi Daerah. Bandung: Alfabeta.

[23] Sullivan, S. and Glanz, J. (2005) Supervision that is Improving Teaching Strategies and Techniques. California: Corwin Press.

[24] Supriyono (2017) Supervisi Pembelajaran Di Sekolah Menengah Pertama (Studi Multisitus pada SMPN1, SMPN 2, SMPN 4 Kota Blitar). Universitas Malang.

[25] Supriyono (2018) 'Model Supervisi Pembelajaran Tim Partisipatif Berbasis Pondok Pesantren'. LPPM UNISBA Blitar.

[26] Supriyono, S. et al. (2017) The Situational Behavior Orientation of Instructional Supervision: A Multisite Study. 2nd International Conference on Educational Management and Administration (CoEMA 2017).

[27]Zepeda, S. J. (2007) Instructional Supervision: Applying Tools and Concepts. Larchmont: NY: Eye on Education.

[28] Zukhrufin, F. K., Anwar, S. and Sidiq, U. (2021) 'Desain Pembelajaran Akhlak Melalui Mata Pelajaran Pendidikan Agama Islam', JIE: Journal of Islamic Edication, 6(2), pp. 17-35. 